\title{
OPTIMASI NANOENKAPSULASI ASAP CAIR TEMPURUNG KELAPA DENGAN RESPONSE SURFACE METHODOLOGY DAN KARAKTERISASI NANOKAPSUL
}

\author{
[Optimization of Coconut Shell Liquid Smoke Nanoencapsulation \\ using Response Surface Methodology and Nanocapsules Characterization]
}

\author{
Dego Yusa Ali1), Purnama Darmadji2)* dan Yudi Pranoto2) \\ 1) Jurusan Teknologi Industri Pertanian, Fakultas Teknologi Pertanian, Universitas Jambi, Jambi \\ 2) Jurusan Teknologi Pangan dan Hasil Pertanian, Fakultas Teknologi Pertanian, Universitas Gadjah Mada, Yogyakarta
}

Diterima 15 November 2013 / Disetujui 07 Februari 2014

\begin{abstract}
Liquid smoke is impractical and easy to deteriorate, thus needs to be protected against deterioration. Spray drying technique is widely used to encapsule bioactive compounds. This study aims to determine the optimum encapsulant ratio and spray drying process to produce nanocapsule of liqud smoke. Nanocapsules production began with the mixing of encapsulant (chitosan and maltodextrin) and the liquid smoke and then agitated until dissolved. The solution of nanoparticles was heated in a water bath at $45^{\circ} \mathrm{C}$ for 5 minutes and homogenized using a homogenizer at $4000 \mathrm{rpm}$ for $1 \mathrm{~min}$. The nanoparticle solutions was spray dried at various temperatures and feed flow rates. Optimization is accomplished by using Response Surface Methodology (RSM), and the parameters to be optimized were chitosan concentration, inlet air temperature and feed flow rate of the spray dryer based on total phenolic content. Samples were analyzed for viscosity, $\mathrm{pH}$, phenols staining, total phenolic, total carbonil, total acidity content, encapsulation efficiency, morphology profiles, and particle size distribution. The results showed that the nanoparticles solution of liquid smoke had a $\mathrm{pH}$ ranged between $2.55-2.64$ total soluble solids ranged between $14-14.8^{\circ}$ Brix and viscosity ranged between $8.7-14.9$ centipoise (cP). The total phenolic content of the nanocapsules ranged from 1.38 to $2.32 \%$ with an efficiency ranged from 22.25 to $37.44 \%$, and water content ranged from 9.56 to $10.73 \%$ (dry basis). The optimum conditions for the highest value of total phenolic content were $0.12 \%$ chitosan concentration, $140.65^{\circ} \mathrm{C}$ inlet air temperature and feed flow rate at $5.29 \mathrm{~mL} / \mathrm{min}$. The results suggested that nanocapsules had spherical and wrinkle shape with an average size of nanocapsules of $29.16 \mathrm{~nm}$.
\end{abstract}

Keywords: liquid smoke, nanoencapsulation, optimization, RSM

\begin{abstract}
ABSTRAK
Asap cair (umumnya) dianggap kurang praktis serta mudah mengalami kerusakan. Oleh karena itu, dikembangkan pembuatan tepung asap dengan metode nanoenkapsulasi. Teknik yang banyak digunakan untuk nanoenkapsulasi adalah teknik spray drying. Penelitian ini bertujuan untuk mengetahui rasio enkapsulan terbaik dan proses spray drying yang optimal. Proses pembuatan nanokapsul diawali dengan mencampurkan enkapsulan (kitosan dan maltodekstrin) ke dalam asap cair, kemudian diaduk sampai larut lalu dihangatkan dalam penangas air pada suhu $45^{\circ} \mathrm{C}$ selama 5 menit. Setelah itu, dilakukan proses homogenisasi (kecepatan $4000 \mathrm{rpm}$, selama 1 menit) dan proses pengeringan dengan spray dryer pada berbagai suhu dan laju alir umpan. Optimasi dilakukan dengan menggunakan metode Response Surface Methodology (RSM), serta parameter yang dioptimasi adalah konsentrasi kitosan, suhu inlet dan laju alir umpan spray dryer terhadap nilai respon total fenol nanokapsul. Analisa yang dilakukan adalah viskositas larutan, pH, pewarnaan fenol, kandungan fenol total, efisiensi enkapsulasi, profil morfologi SEM, dan distribusi ukuran partikel. Dari hasil penelitian didapatkan bahwa larutan nanopartikel asap cair memiliki pH berkisar antara 2.55-2.64 dengan total padatan terlarut berkisar antara $14-14.8^{\circ}$ Brix serta viskositas larutan nanopartikel berkisar antara 8.70-14.90 centipoise (cP). Total fenol nanokapsul berkisar antara 1.38-2.32\% dengan efisiensi berkisar antara 22.25-23.21\%. Kadar air nanokapsul berkisar antara 9.56-10.73\% (dry basis). Dari hasil optimasi, didapatkan kondisi optimum dengan nilai total fenol tertinggi pada konsentrasi kitosan $0.12 \%$, suhu inlet $140.65^{\circ} \mathrm{C}$, dan laju alir umpan $5.29 \mathrm{~mL} /$ menit. Dari hasil uji morfologi didapatkan bentuk partikel yang bulat dan berkerut (shrinkage). Ukuran partikel nanokapsul yang dihasilkan rata-rata sebesar $29.16 \mathrm{~nm}$.
\end{abstract}

Kata kunci: asap cair, nanoenkapsulasi, optimasi, RSM

\section{PENDAHULUAN}

Asap cair tempurung kelapa diketahui mengandung komponen bioaktif seperti fenol, asam, dan karbonil. Oleh sebab itu, asap cair tempurung kelapa memiliki potensi untuk memperpanjang umur simpan produk yang mengandung

*Penulis Korespondensi:

E-mail: purnadj@ugm.ac.id; Hp.: +628122787347 protein (Darmadji et al. 2009; Zuraida et al. 2011). Komponen bioaktif asap cair perlu dilindungi dari kerusakan, salah satunya dengan cara enkapsulasi.

Enkapsulasi merupakan proses penyalutan bahan inti berbentuk cair atau padat menggunakan suatu enkapsulan khusus yang membuat partikel-partikel inti mempunyai sifat fisikokimia yang diinginkan (Deladino et al. 2008). Enkapsulasi menghasilkan partikel dengan diameter mikrometer sampai nanometer (Zuidan dan Nedovic, 2010). Terminologi mikro- 
enkapsulasi dipakai untuk menggantikan istilah enkapsulasi. Dikatakan mikroenkapsulasi karena ukuran partikel yang kecil dari 1-100 $\mu \mathrm{m}$. Teknik mikroenkapsulasi menghasilkan sistem pembawa yang kurang ideal, ukuran partikel relatif besar $(>1$ $\mu \mathrm{m})$ dan bersifat polidispersi sehingga secara termodinamik tidak stabil (Weiss et al. 2008). Enkapsulasi komponen bioaktif pada skala nano telah dikembangkan untuk dapat mengatasi masalah yang berhubungan dengan lambat dan rendahnya serapan dan ketidakstabilan komponen bioaktif pada teknik mikroenkapsulasi (Carvajal et al. 2010). Penelitian nanoenkapsulasi menghasilkan sifat-sifat seperti yang diharapkan yaitu penyimpanan akan lebih baik dan memberikan perlindungan terhadap komponen bioaktif seperti vitamin, antioksidan, pigmen, protein dan lipid serta karbohidrat, sehingga dapat meningkatkan sifat-sifat fungsional dan stabilitasnya (Weiss et al. 2008; Chuah et al. 2009); Tachaprutinun et al. 2009; Carvajal et al. 2010; Sekhon, 2010).

Berbagai macam polimer alami diketahui dapat digunakan untuk pembuatan nanopartikel. Dalam penelitian ini, digunakan kitosan (K) dan maltodekstrin (MD) sebagai enkapsulan untuk asap cair. Dalam penelitian sebelumnya, Saloko et al. (2012), menggunakan kitosan dan maltodekstrin untuk enkapsulasi asap cair dan berhasil membuat produk tepung asap berukuran nanometer (nm). Kitosan secara normal tidak larut dalam air diatas pH 6 karena struktur kristalin yang kaku dan memerlukan asam sebagai donor proton (Lee et al. 2007). Kitosan diharapkan mampu larut dalam asap cair yang memiliki pH 2.0-2.3. Maltodekstrin merupakan salah satu bahan yang umum digunakan untuk enkapsulasi senyawa bioaktif. Maltodekstrin merupakan bahan yang larut air dan dapat melindungi senyawa yang dienkapsulasi dari oksidasi. Berdasarakan penelitian Ahmed et al. (2009), maltodekstrin dapat melindungi kandungan fenol dan antosianin selama proses pembuatan serbuk ekstrak ubi ungu. Salah satu metode yang banyak digunakan untuk enkapsulasi adalah dengan spray drying. Teknik enkapsulasi dengan spray drying merupakan cara yang efektif untuk melindungi komponen bioaktif dari kerusakan dan kehilangan senyawa volatil. Teknik ini sudah banyak dipakai oleh peneliti untuk membuat mikropartikel dari ekstrak buah-buahan (Tonon et al. 2010; Saenz et al. 2009; Kha et al. 2010; Goula dan Adamopoulos, 2010). Dalam teknik spray drying, beberapa faktor penting yang menentukan kualitas produk yang dihasilkan antara lain jenis enkapsulan dan konsentrasinya dalam larutan, suhu inlet udara pengering, dan laju alir umpan. Oleh karena itu, diperlukan optimasi terhadap faktor-faktor tersebut agar produk yang dihasilkan memiliki karakteristik yang baik. Optimasi kondisi spray drying ekstrak buah menggunakan enkapsulan Kkaragenan dan maltodekstrin telah dilakukan oleh Krishnaiah et al. (2009, 2011, 2012).

Response surface methodology (RSM) banyak digunakan untuk menentukan pengaruh tiap faktor dan interaksi antar faktor serta membuat proses optimasi menjadi lebih efektif (Bas dan Boyaci, 2007). Keuntungan dari menggunakan RSM jumlah data yang dibutuhkan untuk evaluasi, analisis dan optimasi secara signifikan mengurangi jumlah percobaan yang dibutuhkan. RSM merupakan metode yang cepat dan ekonomis untuk memperoleh hasil penelitian dibandingkan dengan metode satu variabel dalam satu waktu atau eksperimen faktorial lengkap.
Minitab 14 dan Matlab 2012 merupakan perangkat lunak yang digunakan untuk penelitian ini. Desain eksperimen RSM pada penelitian ini menggunakan desain Box-Behnken.

Tujuan dari penelitian ini adalah optimasi nanoenkapsulasi asap cair dengan rasio konsentrasi kitosan:maltodekstrin, suhu inlet, dan laju alir spray dryer sebagai parameter yang akan dioptimasi terhadap respon nilai total fenolnya. Selanjutnya dilakukan karakterisasi sifat fisik dan morfologi nanokapsul yang dihasilkan.

\section{BAHAN DAN METODE}

\section{Bahan}

Bahan yang digunakan dalam penelitian ini antara lain bahan utama asap cair diperoleh dari pirolisis tempurung kelapa. Maltodekstrin (MD) (Grain Processing Corp. lowa, USA) dengan DE 10.8\% dan kitosan (K) (Biotech Surindo, Indonesia) dengan DD $91.5 \%$.

\section{Preparasi sampel}

Pembuatan larutan nanopartikel mengacu pada penelitian Saloko et al. (2012) dengan modifikasi. Berbagai variasi enkapsulan K $(0.05-0.15 \% \mathrm{~b} / \mathrm{v})$ dan MD $(9.85-9.95 \% \mathrm{~b} / \mathrm{v})$ dilarutkan dalam asap cair $225 \mathrm{~mL}$. Campuran diaduk menggunakan pengaduk magnetik dengan kecepatan 200 rpm selama 30 menit pada suhu ruang. Larutan nanopartikel dihangatkan dalam penangas air (Sibata WS-240, Japan) pada suhu $45^{\circ} \mathrm{C}$ selama 5 menit setelah suhu tercapai dan dilakukan homogenisasi menggunakan homogenizer (Ultraturrax T50 Basic IKA Werke, Germany) pada kecepatan 4000 rpm selama 2 menit.

\section{Kondisi pengeringan}

Larutan nanopartikel diumpankan pada alat spray dryer (Armfield SD04, USA) untuk dilakukan pengeringan. Larutan nanopartikel dikeringkan pada berbagai variasi suhu inlet (125$155^{\circ} \mathrm{C}$ ) dan laju alir (4-6 mL/menit), tekanan pada noozle atomizer 1 bar dengan volume udara pengering tetap. Serbuk nanokapsul yang dihasilkan diambil dari wadah pengumpul hasil, kemudian disimpan pada wadah berlapis alumunium foil lalu disimpan pada suhu ruang sebelum dilakukan karakterisasi.

\section{Nilai $\mathrm{pH}$, viskositas, dan total padatan terlarut larutan nanopartikel}

Alat pH-meter (Schott, Deutschland, Germany) digunakan untuk mengukur $\mathrm{pH}$ larutan nanopartikel pada suhu $26^{\circ} \mathrm{C}$. Viskositas ditentukan dengan cara menempatkan $250 \mathrm{~mL}$ larutan nanopartikel pada wadah silinder dengan volume 300 $\mathrm{mL}$, kemudian diukur menggunakan viskometer Brookfield RVT Type (Middleboro, USA) pada $25^{\circ} \mathrm{C}$, spindle No. 1 dengan putaran $100 \mathrm{rpm}$ selama 30 detik. Total padatan terlarut diukur menggunakan hand-held refractometer ukuran N1 (Atago, Tokyo, Japan) pada $20^{\circ} \mathrm{C}$, dan dipresentasikan sebagai derajat Brix ( ${ }^{\circ}$ Brix).

\section{Pewarnaan fenol}

Larutan $\mathrm{FeCL}_{3}$ 5\% (J.T. Baker, USA) berwarna kuning ditambahkan ke dalam asap cair dengan perbandingan (3 tetes: $1 \mathrm{~mL}$ ). Campuran berwarna merah kecoklatan diaduk per- 
lahan, kemudian ditambahkan enkapsulan lalu diaduk menggunakan magnetic stirrer dengan kecepatan 400 rpm selama 30 menit. Larutan nanopartikel berwarna dilihat menggunakan mikroskop cahaya (Olympus CX 21, Olympus Corp, Japan) dengan bantuan software OPTILAB.

\section{Total fenol}

Analisis total fenol mengacu pada metode Senter et al. (1989) dengan modifikasi. Sebanyak $1 \mathrm{~mL}$ asap cair ditimbang atau $1 \mathrm{~g}$ nanokapsul asap cair diencerkan menjadi $25 \mathrm{~mL}$, diambil $1 \mathrm{~mL}$ diencerkan lagi menjadi $10 \mathrm{~mL}$ (faktor pengenceran $=250 \mathrm{x}$ ), diambil $2.5 \mathrm{~mL}$ diencerkan lagi menjadi $10 \mathrm{~mL}$ (faktor pengenceran $=1000 \mathrm{x}$ ). $1 \mathrm{~mL}$ hasil pengenceran terakhir dimasukkan dalam tabung reaksi kemudian ditambahkan $1 \mathrm{~mL}$ $\mathrm{Na}_{2} \mathrm{CO}_{3}$ (Merck, Germany) jenuh dan dibiarkan selama 10 menit pada suhu kamar. Selanjutnya ditambahkan $0.5 \mathrm{~mL}$ reagen folinciocalteau (Merck, Germany) dan $7.5 \mathrm{~mL}$ aquades, dihomogenkan dengan vortex kemudian dibiarkan selama 30 menit pada suhu ruang. Sampel tersebut diukur pada panjang gelombang $770 \mathrm{~nm}$. Kadar fenol sampel dihitung berdasarkan persamaan kurva standar yang diperoleh.

\section{Kadar air}

Pengukuran kadar air dilakukan secara gravimetric mengikuti metode AOAC (2005). Sampel sebanyak 1 gram (a) dimasukkan kedalam botol timbang yang telah dikeringkan dalam oven pada suhu $105^{\circ} \mathrm{C}$ dan telah diketahui berat konstannya. Sampel dikeringkan pada suhu $105^{\circ} \mathrm{C}$ selama 10 jam kemudian ditimbang. Sampel dikeringkan kembali kemudian ditimbang setiap 2 jam hingga berat konstan (selisih bobot sampel pada tiap penimbangan kurang dari $0.2 \mathrm{mg}$ ). Pengurangan berat merupakan banyaknya air dalam sampel yang dihitung dengan rumus:

$$
\text { Kadar air }(\% d b)=\frac{(a-b)}{b} \times 100 \%
$$

\section{Efisiensi enkapsulasi}

Efisiensi enkapsulasi dihitung berdasarkan total fenolnya. Total fenol nanokapsul asap cair dianalisis dengan menggunakan metode Senter et al. (1989). Perhitungan efisiensi enkapsulasi mengacu pada metode Belscak-Cvitanovic et al. (2011), yaitu persentase efisiensi enkapsulasi dihitung sebagai rasio antara kadar fenol dalam mikrokapsul asap cair dengan kadar fenol dalam asap cair.

$$
\text { Efisiensi enkapsulasi }(\%)=\frac{\text { Fenol mikrokapsul }}{\text { Fenol awal }} \times 100 \%
$$

$$
\text { Kadar fenol awal }(\%)=\frac{\text { Fenol asap cair } \times \mathrm{g} \text { asap cair }}{\mathrm{g} \text { total padatan }} \times 100 \%
$$

\section{Profil morfologi menggunakan Scanning Electron Microscope (SEM)}

Scanning Electron Microscope (SEM FEI tipe Inspect S50, Oregon, USA) digunakan untuk mempelajari profil morfologi permukaan nanokapsul. Partikel nanokapsul ditempelkan pada SEM stubs dengan diameter $10 \mathrm{~mm}$ menggunakan pita perekat dua sisi. Kemudian sampel dilapisi dengan emas dan dilihat pada perbesaran $10000 \mathrm{x}$ dengan voltase $20 \mathrm{kV}$.

\section{Analisis distribusi ukuran partikel}

Dispersi nanokapsul dalam aquades diukur menggunakan alat laser particle size analyzer (Malvern Zetasizer Nanoseries Nano ZS ver 6.20, Malvern Instruments Ltd, Malvern, UK) dengan metode Dynamic Light Scattering. Distribusi ukuran partikel ditentukan dengan nilan span (span value). Pengukuran dilakukan sebanyak 3 kali.

\section{Desain eksperimen}

Response surface methodology (RSM) diterapkan menggunakan Minitab 14 untuk mengidentifikasi level optimum dari tiga variabel konsentrasi kitosan $(\% \mathrm{~b} / \mathrm{v})$, suhu inlet $\left({ }^{\circ} \mathrm{C}\right)$, dan laju alir umpan ( $\mathrm{mL} /$ menit). Variabel terkode dan tak terkode yang digunakan pada desain RSM dapat dilihat pada Tabel 1.

Tabel 1. Kode level (variabel independen) optimasi

\begin{tabular}{ccccc}
\hline & \multicolumn{3}{c}{ Level Tak Terkode } \\
\cline { 3 - 5 } & & $\begin{array}{c}\text { Konsentrasi } \\
\text { Kitosan }\left(\mathrm{X}_{1}\right) \\
(\% \mathrm{~b} / \mathrm{v})\end{array}$ & $\begin{array}{c}\text { Suhu Inlet } \\
\left(\mathrm{X}_{2}\right) \\
\left({ }^{\circ} \mathrm{C}\right)\end{array}$ & $\begin{array}{c}\text { Laju Alir } \\
\left(\mathrm{X}_{3}\right) \\
(\mathrm{mL} / \mathrm{menit})\end{array}$ \\
\hline Level & +1 & 0.05 & 125 & 4 \\
terkode & 0 & 0.1 & 140 & 5 \\
& -1 & 0.15 & 155 & 6 \\
\hline
\end{tabular}

Dari penelitian pendahuluan diketahui titik optimum dari konsentrasi kitosan, suhu inlet, dan laju alir yang memberikan nilai total fenol tertinggi secara berturut-turut adalah $0.1 \%$, $140^{\circ} \mathrm{C}$, dan $5 \mathrm{~mL} /$ menit yang akan dijadikan sebagai titik pusat pada rancangan RSM. Eksperimen dirancang menggunakan desain Box-Behnken yang dapat dilihat pada Tabel 1. Data respon dianalisis koefisien regresi, variansi, nilai eigen, dan optimasi respon.

\section{HASIL DAN PEMBAHASAN}

\section{Hasi pewarnaan fenol}

Asap cair memiliki penampakan cairan jernih berwarna kekuningan dengan aroma seperti asap dan juga memiliki aroma asam dan fenolik. Adanya aroma fenolik pada asap cair dikarenakan asap cair mengandung komponen senyawa fenol hasil degradasi lignin. Salah satu metode kualitatif untuk membuktikan bahwa di dalam asap cair terdapat senyawa fenol adalah dengan mereaksikan asap cair dengan senyawa ferri klorida $\left(\mathrm{FeCl}_{3}\right.$ ). Menurut Soloway dan Wilen (1952), feri klorida dalam larutan memberikan warna dengan beberapa senyawa organik, salah satunya fenol. Warna yang dihasilkan berbedabeda sesuai dengan jenis senyawa fenolnya. Feri klorida bereaksi dengan guaiakol menghasilkan warna merah. Dengan demikian, warna merah hasil pengecatan fenol asap cair mengindikasikan bahwa asap cair yang digunakan mengandung guaiakol.

Hasil analisis pewarnaan fenol pada asap cair dan larutan nanopartikel menunjukkan adanya reaksi antara feri klorida dengan senyawa fenol yang terkandung dalam asap cair. Hal tersebut ditunjukkan pada Gambar 1. Pengamatan dengan 
menggunakan mikroskop cahaya pada perbesaran 1000x menunjukkan bahwa asap cair maupun larutan nanopartikel tanpa penambahan $\mathrm{FeCl}_{3}$ berbentuk bulatan-bulatan transparan (tidak berwarna), sedangkan asap cair dan larutan nanopartikel dengan penambahan $\mathrm{FeCl}_{3}$ berbentuk bulatan dengan warna kecoklatan. Hal ini mengindikasikan bahwa senyawa feno dalam asap cair yang berwarna merah dapat terkapsul oleh maltodekstrin dan kitosan. Pada larutan nanopartikel terlihat terdapat dua lapisan pada bulatan partikel. Untuk menentukan mekanisme penyalutan atau posisi penyalut perlu dilakukan penelitian lebih lanjut.
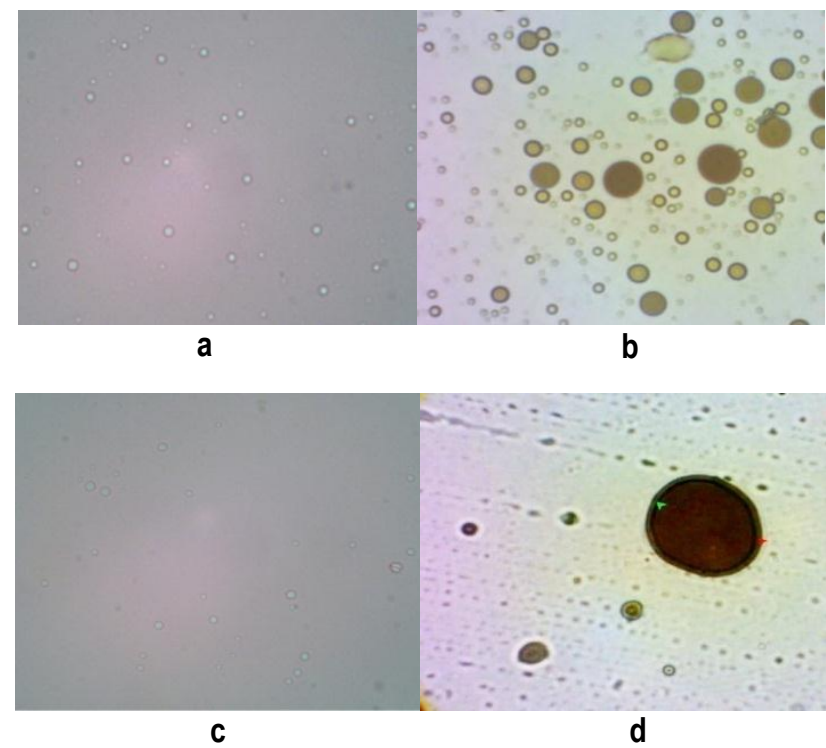

Gambar 1. Pewarnaan fenol. a) Asap cair; b) Asap cair + $\mathrm{FeCl}_{3}$; c) Larutan nanopartikel asap cair + maltodekstrin + kitosan; d) Larutan nanopartikel asap cair + maltodekstrin + kitosan $+\mathrm{FeCl}_{3}$

\section{Viskositas, pH dan total padatan terlarut larutan nano- partikel}

Dari analisis viskositas larutan nanopartikel pada berbagai konsentrasi, didapatkan hasil semakin tinggi konsentrasi kitosan di dalam larutan, maka semakin tinggi nilai viskositasnya dengan nilai total padatan terlarut dan $\mathrm{pH}$ yang relatif sama. Hal ini disebabkan karena semakin tinggi konsentrasi kitosan di dalam larutan, maka akan mengurangi kelarutan kitosan dalam larutan nanopartikel, sehingga nanopartikel kitosan tidak bisa terdispersi menjadi ukuran yang lebih kecil, sehingga viskositasnya semakin besar. Nilai viskositas larutan nanopartikel dapat dilihat pada Tabel 2. Berdasarkan hasil analisis statistik (Tabel 4) untuk viskositas, konsentrasi kitosan berbeda nyata pada taraf kepercayaan $p<0.05$. Nilai rataan viskositas untuk konsentrasi kitosan $0.05,0.10$, dan $0.15 \%$ secara berturut-turut adalah 8.55, 10.86, dan $14.75 \mathrm{cP}$.

Fernandez-Kim (2004) menyebutkan bahwa apabila ukuran rantai polimer kitosan bertambah kecil, laju gerakan translasinya menjadi semakin cepat, sehingga viskositas larutannya bertambah rendah. Analisis viskositas larutan nanopartikel berguna untuk mengetahui apakah partikel dalam larutan tersebut dapat terdispersi dengan baik dan tidak mengalami aglomerasi agar dapat dilakukan proses pengeringan dengan spray dryer.

Tabel 2. Nilai viskositas dan total padatan terlarut larutan nanopartikel

\begin{tabular}{cccc}
\hline $\begin{array}{c}\text { Sampel } \\
([\mathrm{K}])\end{array}$ & $\begin{array}{c}\text { Viskositas } \\
(\mathrm{cP})\end{array}$ & $\begin{array}{c}\text { Total Padatan Terlarut } \\
\left({ }^{\circ} \text { Brix }\right)\end{array}$ & $\begin{array}{c}\mathrm{pH} \\
\left(28^{\circ} \mathrm{C}\right)\end{array}$ \\
\hline $1(0.05)$ & 8.8 & 14.2 & 2.55 \\
$2(0.15)$ & 14.8 & 14.6 & 2.57 \\
$3(0.05)$ & 8.2 & 14.2 & 2.56 \\
$4(0.15)$ & 14.5 & 14.8 & 2.58 \\
$5(0.05)$ & 8.7 & 14.2 & 2.57 \\
$6(0.15)$ & 14.8 & 14.6 & 2.58 \\
$7(0.05)$ & 8.5 & 14.4 & 2.56 \\
$8(0.15)$ & 14.9 & 14.6 & 2.58 \\
$9(0.1)$ & 11.2 & 14.6 & 2.59 \\
$10(0.1)$ & 11.2 & 14.4 & 2.60 \\
$11(0.1)$ & 11.2 & 14.4 & 2.61 \\
$12(0.1)$ & 11.2 & 14.2 & 2.58 \\
$13(0.1)$ & 10.4 & 14.6 & 2.62 \\
$14(0.1)$ & 10.6 & 14.4 & 2.60 \\
$15(0.1)$ & 10.4 & 14.6 & 2.58 \\
\hline
\end{tabular}

Keterangan: [K]: konsentrasi kitosan

\section{Kadar air nanokapsul}

Kadar air nanokapsul dipengaruhi oleh beberapa faktor, antara lain konsentrasi enkapsulan (Sormoli et al. 2012), suhu inlet spray dryer (Caliskan dan Nur, 2013), dan laju alir umpan spray dryer (Yuliana et al. 2007). Dari hasil penelitian (Tabel 4), konsentrasi kitosan berpengaruh terhadap kadar air nanokapsul yang dihasilkan. Semakin besar konsentrasi kitosan, maka semakin rendah kadar air nanokapsul. Berdasarkan analisis statistik, kitosan $0.15 \%$ berbeda nyata dengan kitosan $0.05 \%$ pada selang kepercayaan $(p<0.05)$. Kadar air untuk berbagai variasi konsentrasi kitosan yaitu 10.24, 10.14, dan $10.08 \%$ untuk konsentrasi kitosan $0.05,0.10$, dan $0.15 \%$. Berdasarkan hasil tersebut, konsentrasi kitosan semakin tinggi, maka kadar air semakin rendah. Hal tesebut dapat disebabkan ukuran partikel kitosan yang lebih kecil membuat luas permukaan kontak dengan udara pengering semakin luas. Pada suhu inlet dan laju alir yang sama, ukuran partikel yang lebih kecil mengakibatkan efisiensi proses evaporasi air meningkat, karena jarak yang dibutuhkan air berdifusi dari dalam keluar partikel menjadi lebih singkat, sehingga produk menjadi lebih kering. Hal ini sesuai dengan penelitian Learoyd et al. (2008) bahwa kitosan bubuk yang dibuat dengan proses spray dryer memiliki kadar air yang lebih tinggi pada prtikel berukuran lebih besar.

Variasi perlakuan suhu inlet yang dilakukan pada penelitian ini menunjukkan bahwa semakin tinggi suhu inlet spray dryer yang yang digunakan, maka semakin rendah kadar air nanokapsul yang dihasilkan. Hal ini disebabkan karena suhu pengeringan yang tinggi akan menguapkan air dalam jumlah yang lebih besar. Berdasarkan hasil analisis variansi, nilai kadar air untuk masing-masing variasi perlakuan suhu berbeda nyata pada selang kepercayaan $(p<0.05)$, dengan nilai rata-rata kadar air nanokapsul yang dihasilkan sebesar 10.49, 10.14, dan $9.81 \%$ untuk variasi suhu 125,140 , dan $155^{\circ} \mathrm{C}$. Data kadar air nanokapsul dapat dilihat pada Tabel 3 dan analisis varian untuk kadar air dapat dilihat pada Tabel 4. 
Tabel 3. Kondisi rancangan percobaan dan hasil

\begin{tabular}{|c|c|c|c|c|c|c|c|c|c|}
\hline \multirow{3}{*}{$\begin{array}{l}\text { Sampel } \\
\text { No. }\end{array}$} & Faktor 1 & Faktor 2 & Faktor 3 & Faktor 1 & Faktor 2 & Faktor 3 & \multirow{2}{*}{\multicolumn{3}{|c|}{ Nilai Respon }} \\
\hline & $X_{1}$ & $X_{2}$ & $x_{3}$ & $\begin{array}{l}\text { Konsentrasi } \\
\text { Kitosan (\%) }\end{array}$ & $\begin{array}{c}\text { Suhu Inlet } \\
\left({ }^{\circ} \mathrm{C}\right)\end{array}$ & $\begin{array}{c}\text { Laju Alir } \\
\text { (mL/menit) }\end{array}$ & & & \\
\hline & \multicolumn{3}{|c|}{ Level Terkode } & \multicolumn{3}{|c|}{ Level Tak Terkode } & Total Fenol (\%) & Kadar Air (\%) & Efisiensi Enkapsulasi (\%) \\
\hline 1 & -1 & -1 & 0 & 0.05 & 125 & 5 & $1.38 \pm 0.06$ & $10.73 \pm 0.09$ & $22.25 \pm 1.04$ \\
\hline 2 & 1 & -1 & 0 & 0.15 & 125 & 5 & $1.99 \pm 0.04$ & $10.49 \pm 0.37$ & $31.98 \pm 0.70$ \\
\hline 3 & -1 & 1 & 0 & 0.05 & 155 & 5 & $1.52 \pm 0.03$ & $9.87 \pm 0.09$ & $24.42 \pm 0.62$ \\
\hline 4 & 1 & 1 & 0 & 0.15 & 155 & 5 & $1.92 \pm 0.01$ & $9.56 \pm 0.20$ & $30.96 \pm 0.18$ \\
\hline 5 & -1 & 0 & -1 & 0.05 & 140 & 4 & $1.43 \pm 0.04$ & $9.95 \pm 0.24$ & $23.05 \pm 0.74$ \\
\hline 6 & 1 & 0 & -1 & 0.15 & 140 & 4 & $1.85 \pm 0.07$ & $10.11 \pm 0.07$ & $29.86 \pm 1.20$ \\
\hline 7 & -1 & 0 & 1 & 0.05 & 140 & 6 & $1.75 \pm 0.03$ & $10.38 \pm 0.14$ & $28.15 \pm 0.64$ \\
\hline 8 & 1 & 0 & 1 & 0.15 & 140 & 6 & $2.08 \pm 0.07$ & $10.15 \pm 0.18$ & $33.46 \pm 1.23$ \\
\hline 9 & 0 & -1 & -1 & 0.1 & 125 & 4 & $1.76 \pm 0.04$ & $10.15 \pm 0.12$ & $28.28 \pm 0.69$ \\
\hline 10 & 0 & 1 & -1 & 0.1 & 155 & 4 & $1.75 \pm 0.04$ & $9.80 \pm 0.14$ & $28.17 \pm 0.72$ \\
\hline 11 & 0 & -1 & 1 & 0.1 & 125 & 6 & $1.84 \pm 0.04$ & $10.58 \pm 0.25$ & $29.61 \pm 0.70$ \\
\hline 12 & 0 & 1 & 1 & 0.1 & 155 & 6 & $2.00 \pm 0.07$ & $10.01 \pm 0.20$ & $32.21 \pm 1.23$ \\
\hline 13 & 0 & 0 & 0 & 0.1 & 140 & 5 & $2.20 \pm 0.04$ & $10.13 \pm 0.06$ & $35.44 \pm 0.69$ \\
\hline 14 & 0 & 0 & 0 & 0.1 & 140 & 5 & $2.32 \pm 0.04$ & $10.15 \pm 0.09$ & $37.44 \pm 0.66$ \\
\hline 15 & 0 & 0 & 0 & 0.1 & 140 & 5 & $2.31 \pm 0.01$ & $10.13 \pm 0.02$ & $37.17 \pm 0.24$ \\
\hline
\end{tabular}

Tabel 4. Analisis varian pengaruh masing-masing variabel terhadap sifat fisik nanokapsul

\begin{tabular}{|c|c|c|c|c|}
\hline \multicolumn{2}{|c|}{$\begin{array}{l}\text { Karakteristik } \\
\text { Nanokapsul }\end{array}$} & $\begin{array}{c}\begin{array}{c}\text { Kadar Air } \\
(\% \mathrm{db})\end{array} \\
\end{array}$ & $\begin{array}{c}\text { Efisiensi } \\
\text { Enkapsulasi (\%) }\end{array}$ & $\begin{array}{c}\text { Viskositas } \\
(\mathrm{CP})\end{array}$ \\
\hline \multirow{3}{*}{$\begin{array}{l}\text { Konsen- } \\
\text { trasi } \\
\text { kitosan } \\
(\%)\end{array}$} & 0.05 & $10.24 \pm 0.38^{b}$ & $24.47 \pm 2.46^{a}$ & $8.55 \pm 0.24^{a}$ \\
\hline & 0.1 & $10.14 \pm 0.25^{\mathrm{ab}}$ & $32.62 \pm 3.92^{c}$ & $10.86 \pm 0.38^{b}$ \\
\hline & 0.15 & $10.07 \pm 0.40^{a}$ & $31.57 \pm 1.60^{b}$ & $14.75 \pm 0.16^{c}$ \\
\hline \multirow{3}{*}{$\begin{array}{l}\text { Suhu inlet } \\
\left({ }^{\circ} \mathrm{C}\right)\end{array}$} & 125 & $10.49 \pm 0.30 c$ & $28.03 \pm 3.81^{a}$ & - \\
\hline & 140 & $10.14 \pm 0.16^{b}$ & $32.08 \pm 5.09 c$ & - \\
\hline & 155 & $9.81 \pm 0.33^{a}$ & $28.94 \pm 3.20^{b}$ & - \\
\hline \multirow{3}{*}{$\begin{array}{l}\text { Laju alir } \\
\text { umpan } \\
\text { (mL/menit) }\end{array}$} & 4 & $10.00 \pm 0.20^{a}$ & $27.34 \pm 2.78^{a}$ & - \\
\hline & 5 & $10.15 \pm 0.39 b$ & $31.38 \pm 5.76^{b}$ & - \\
\hline & 6 & $10.28 \pm 0.33^{b}$ & $30.86 \pm 2.34^{b}$ & - \\
\hline
\end{tabular}

${ }^{\star}$ Nilai merupakan rataan \pm standar error

a,b,cNilai pada kolom yang diikuti dengan huruf berbeda menunjukkan perbedaan nyata pada $p<0.05$ (Duncan's multiple range test)

Berlawanan dengan suhu inlet, semakin tinggi laju aliran umpan, maka kadar air nanokapsul yang dihasilkan semakin rendah. Berdasarkan hasil analisis varian, nilai kadar air untuk perlakuan laju alir umpan $4 \mathrm{~mL} /$ menit berbeda nyata dengan laju alir 5 dan $6 \mathrm{~mL} /$ menit, sedangkan untuk perlakuan laju alir 5 $\mathrm{mL} /$ menit tidak berbeda nyata dengan laju alir $6 \mathrm{~mL} / \mathrm{menit}$. Nilai rata-rata kadar air nanokapsul yang dihasilkan sebesar 10.0, 10.15, dan $10.28 \%$ untuk perlakuan laju alir 4, 5, dan 6 $\mathrm{mL} /$ menit. Laju alir umpan yang lebih cepat mengakibatkan jumlah air yang diuapkan akan lebih kecil. Hal ini karena aliran bahan yang berjalan lebih cepat akan menyebabkan kontak bahan dengan udara kering akan berlangsung lebih singkat sementara jumlah total air dalam larutan sama jumlahnya. Akibatnya jumlah air yang diuapkan akan lebih kecil daripada jika laju alir umpan yang digunakan lebih rendah.

\section{Efisiensi enkapsulasi}

Efisiensi enkapsulasi merupakan salah satu parameter yang dapat digunakan untuk menentukan keberhasilan proses enkapsulasi. Parameter ini menunjukkan berapa persen senyawa aktif (fenol) yang berhasil dikungkung atau dilindungi dalam kapsul. Berdasarkan hasil penelitian, perbedaan konsentrasi kitosan menyebabkan nilai efisiensi enkapsulasi berbeda. Variasi perlakuan konsentrasi kitosan berbeda nyata pada tiap taraf pada selang kepercayaan $(p<0.05)$. Efisiensi enkapsulasi terbesar diperoleh pada nanokapsul dengan konsentrasi kitosan $0.1 \%$. Nilai efisiensi enkapsulasi untuk kitosan $0.05,0.1$, dan $0.15 \%$ secara berturut-turut adalah $24.47,32.62$, dan $31.57 \%$. Efisiensi enkapsulasi nanokapsul dengan konsentrasi kitosan kurang dari $0.1 \%$ dan lebih besar dari $0.1 \%$ memiliki efisiensi lebih kecil dibandingkan nanokapsul dengan konsentrasi kitosan $0.1 \%$. Data efisiensi enkapsulasi dapat dilihat pada Tabel 3. Peningkatan konsentrasi kitosan yang lebih tinggi dapat menyebabkan kitosan menjadi tidak larut. Kondisi ini menyebabkan terjadinya celah-celah (crack) pada lapisan (crust) sehingga komponen flavor berdifusi keluar melalui celah-celah yang terbentuk.

Menurut Rosenberg et al. (1990), konsentrasi padatan mempengaruhi viskositas dan berperan terhadap kehilangan komponen volatil. Viskositas berpengaruh terhadap pergerakan komponen volatil ke permukaan droplet yang dikeringkan. Viskositas dapat dinaikkan sampai nilai optimal untuk meningkatkan retensi. Apabila viskositas terus dinaikkan akan menurunkan retensi komponen flavor. Berdasarkan hasil penelitian, efisiensi enkapsulasi mengalami peningkatan sampai suhu inlet $140^{\circ} \mathrm{C}$, kemudian mengalami penurunan. Efisiensi enkapsulasi terbesar diperoleh pada perlakuan suhu inlet $140^{\circ} \mathrm{C}$, yaitu sebesar $32.08 \%$ hampir sama dengan perlakuan suhu inlet, efisiensi enkapsulasi untuk parameter laju alir meningkat sampai laju alir $5 \mathrm{~mL} /$ menit, setelah itu efisiensi menurun walaupun secara statistik penurunannya tidak signifikan. 
Efisiensi enkapsulasi terbesar didapat pada taraf perlakuan laju alir $5 \mathrm{~mL} /$ menit, yaitu sebesar $31.38 \%$. Hal ini disebabkan oleh peningkatan suhu inlet dan laju alir membuat proses pengeringan lebih baik dan pembentukan nanokapsul lebih sempurna sampai pada batas tertentu (titik optimal).

Penelitian ini, nilai efisiensi enkapsulasi yang rendah pada suhu minimum $\left(<140^{\circ} \mathrm{C}\right)$, dapat disebabkan oleh kehilangan senyawa fenol selama periode pengeringan yang tidak stabil yaitu sebelum struktur partikel terbentuk. Di sisi lain, efisiensi enkapsulasi yang lebih rendah pada suhu maksimum $\left(>140^{\circ} \mathrm{C}\right)$ dapat disebabkan oleh laju pengeringan yang tinggi, sehingga evaporasi terjadi sangat cepat setelah proses atomisasi menyebabkan pengembangan yang tidak terkontrol dan kerusakan pada permukaan partikel sehingga senyawa fenol mudah hilang, terutama senyawa fenol yang memiliki titik didih lebih rendah.

\section{Variabel optimum terhadap respon total fenol}

Optimasi merupakan proses pencarian nilai-nilai variabel yang dianggap optimal, efektif dan efisien untuk mencapai hasil yang diinginkan. Dalam penelitian ini, hasil yang dinginkan adalah nanokapsul asap cair dengan nilai total fenol terbesar. Setelah semua perlakuan dilaksanakan, kemudian dicari hubungan orde dua dari persamaan repon dengan variabel bebas. Persamaan yang diperoleh dari total fenol $(Y)$ dengan konsentrasi kitosan $\left(X_{1}\right)$, Suhu inlet $\left(X_{2}\right)$, dan Laju alir umpan $\left(X_{3}\right)$ adalah:

\section{$Y=2.27667+0.22 X_{1}+0.0275 X_{2}+0.11 X_{3}-0.31708 X_{1}^{2}-$ $0.25708 X_{2}{ }^{2}-0.18208 X_{3}{ }^{2}-0.0525 X_{1} X_{2}-0.0225 X_{1} X_{3}+$ $0.0425 X_{2} X_{3}$}

Untuk signifikansi model yang menunjukkan kesusaian hubungan respon dengan faktor, model linear dan model kuadrat mempunyai nilai $p$ ( $p$-value) yang kecil $(<0.5)$ sedangkan model nonlinear yang mengikutsertakan interaksi antar faktor, nilai $p>0.05$. Sehingga model yang tepat untuk hubungan pengembangan dengan konsentrasi kitosan, suhu inlet, dan laju alir umpan adalah model kuadratik (nilai $p$-nya $<0.05$ ).

Grafik kontur dan permukaan persamaan diatas dapat dilihat pada Gambar 2. Pada gambar permukaan terlihat bahwa kurva yang terbentuk merupakan parabola terbalik, dari gambar tersebut dapat diprediksi bahwa respon akan dalam bentuk maksimal. Begitu juga dengan kontur, semua variasi tingkat 2 faktor yang berpengaruh pada nilai total fenol mempunyai 1 titik pusat. Nilai eigen dari matrik persamaan bernilai negatif semua, yang menunjukkan bahwa respon berada diposisi maksimum sesuai dengan yang diharapkan (total fenol terbesar). Dari hasil perhitungan optimasi diperoleh total fenol optimum sebesar $2.233 \%$. Nilai tersebut diperoleh pada kondisi konsentrasi kitosan $0.1167 \%$, uhu inlet $140.65^{\circ} \mathrm{C}$ dan laju alir umpan 5.29 $\mathrm{mL} /$ menit, dengan nilai desirability 1 , yang artinya sangat mendekati sempurna antara target dengan hasil optimasi. Pada kondisi nanoenkapsulasi yang optimum diperoleh karakteristik nanokapsul asap cair: kadar air $10.14 \%$, efisiensi enkapsulasi $32.96 \%$.
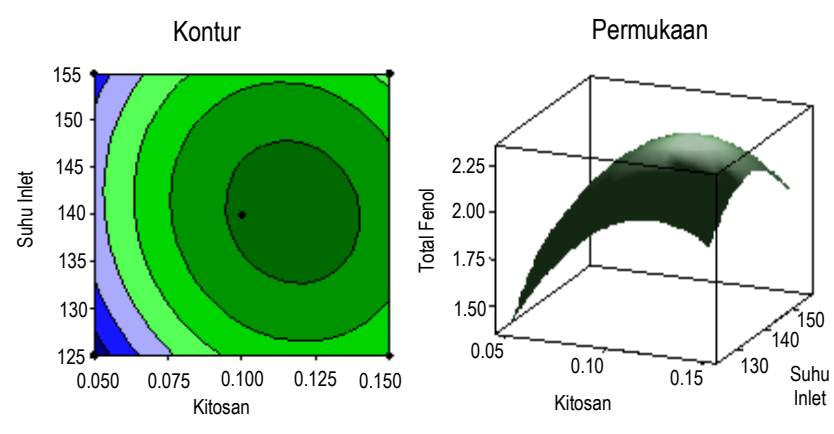

Konsentrasi Kitosan vs Suhu Inlet
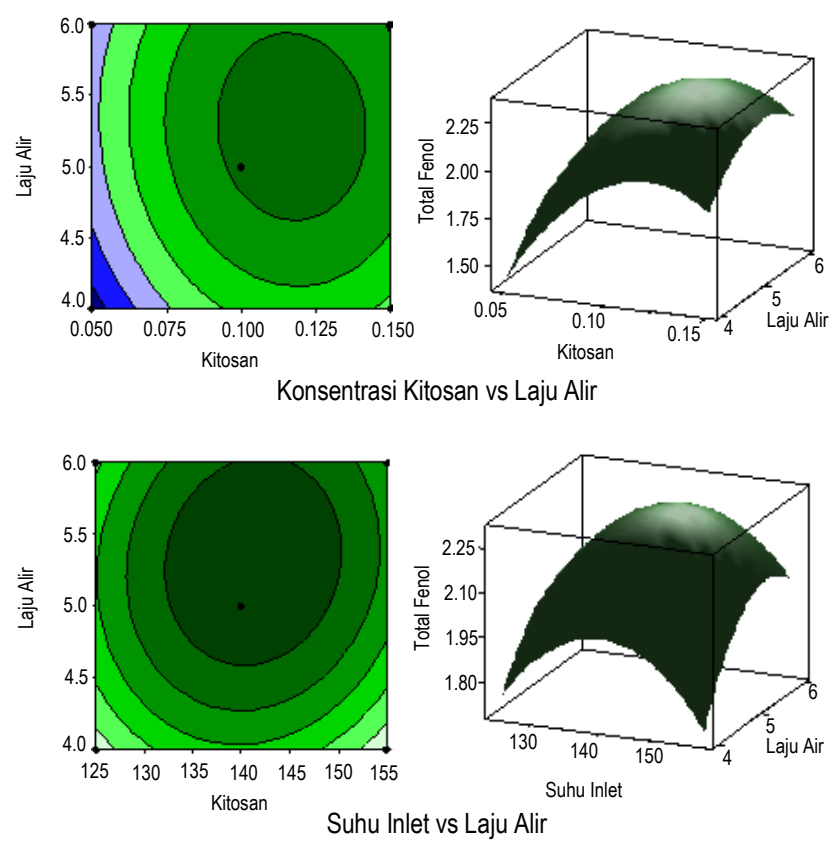

Gambar 2. Grafik kontur dan permukaan respon total fenol pada kondisi optimum

\section{Profil morfologi nanokapsul}

Morfologi nanokapsul mempengaruhi sifat nanokapsul lainnya seperti laju pelepasan senyawa aktif, retensi dan lain-lain. Pada penelitian ini digunakan teknik Scanning Electron Microscopy (SEM) untuk mengetahui struktur nanokapsul. Analisis profil morfologi ini hanya dilakukan pada perlakuan yang optimum (konsentrasi kitosan $0.1 \%$, suhu inlet $140^{\circ} \mathrm{C}$, laju alir $5 \mathrm{~mL} / \mathrm{menit}$ ) dan dibandingkan dengan kontrol (maltodekstrin, suhu inlet $140^{\circ} \mathrm{C}$, laju alir $5 \mathrm{~mL} /$ menit). Dari Gambar 3 terlihat bahwa pada nanokapsul kontrol (hanya menggunakan maltodekstrin sebagai enkapsulan) terdapat keretakan pada mikrokapsul (ditunjukkan dengan tanda panah). Keretakan ini dapat terjadi karena suhu pengeringan yang tinggi. Yuliana et al. (2007) berpendapat bahwa keretakan mikrokapsul dapat memacu tingkat pelepasan bahan aktif. Hal ini ditunjukkan pada penelitian pendahuluan dimana nanokapsul yang tanpa penambahan kitosan sebagai enkapsulan memiliki nilai total fenol yang lebih rendah. 
Dari Gambar 3 juga dapat dilihat bahwa nanokapsul dari perlakuan yang optimum memiliki bentuk bulat namun mengkerut. Bentuk nanokapsul yang mengkerut dapat disebabkan oleh penguapan air yang cepat pada saat proses spray drying. Morfologi yang hampir sama juga ditunjukkan oleh Harris et al. (2010) dimana mikrokapsul yang dihasilkan berbentuk bulat dan bergelombang yang disebabkan oleh penguapan pelarut yang cepat pada saat proses spray drying.

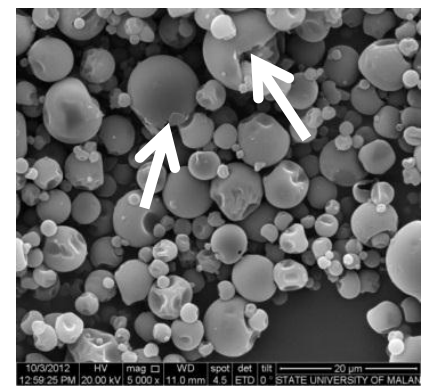

a

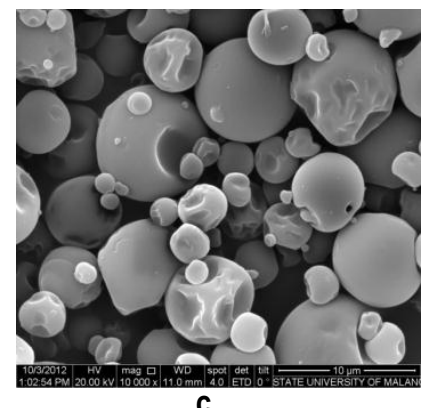

C

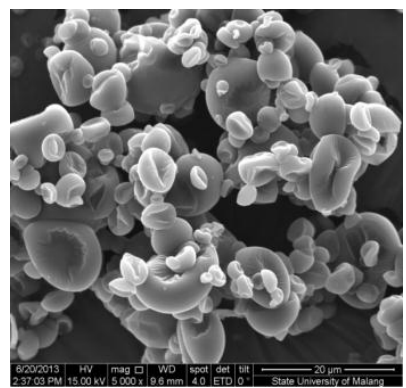

b

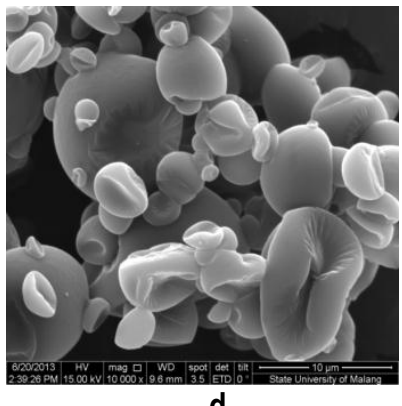

Gambar 3. Morfologi SEM nanokapsul asap cair: (a) Maltodekstrin $(10 \% \mathrm{~b} / \mathrm{v})(5000 \mathrm{x})$; (b) Maltodekstrin $(9.9 \% \mathrm{~b} / \mathrm{v})+$ kitosan $(0.1 \% \mathrm{~b} / \mathrm{v})(5000 \mathrm{x}) ;$ (c) Maltodekstrin $(10 \% \mathrm{~b} / \mathrm{v})(10000 \mathrm{x})$; (d) Maltodekstrin $(9.9 \% \mathrm{~b} / \mathrm{v})+$ kitosan $(0.1 \% \mathrm{~b} / \mathrm{v})(10000 \mathrm{x})$

\section{Distribusi ukuran partikel}

Pengukuran distribusi partikel bertujuan untuk mengetahui sebaran ukuran nanokapsul asap cair. Pengukuran ini dilakukan untuk mengetahui apakah metode yang digunakan dan kitosan sebagai enkapsulan bisa membuat nanokapsul berukuran nano $\left(10^{-9} \mathrm{~m}\right)$. Dari Gambar 4 dapat dilihat bahwa ukuran partikel nanokapsul asap cair terdistribusi mulai dari rata-rata ukuran $18.18 \mathrm{~nm}(70.5 \%), 276.1 \mathrm{~nm}(23.4 \%)$ sampai $5.02 \mu \mathrm{m}(6.1 \%)$. Secara keseluruhan, partikel nanokapsul berukuran $29.16 \mathrm{~nm}$.

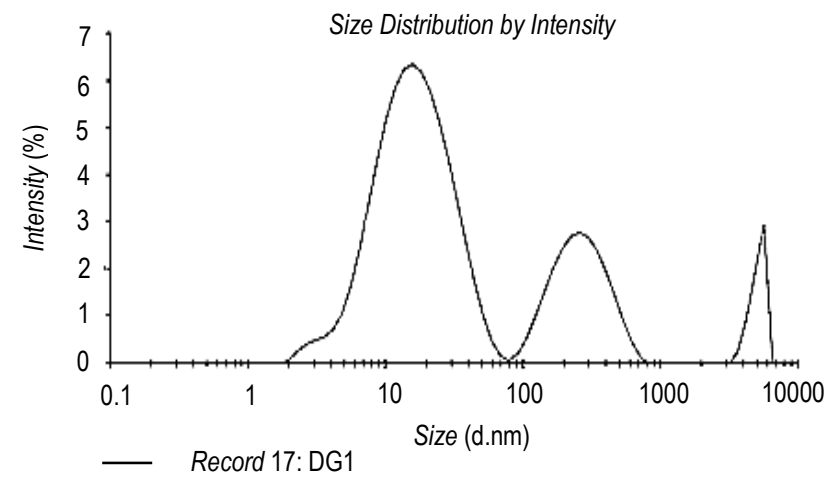

Gambar 4. Distribusi ukuran partikel nanokapsul asap cair
Dari hasil pengukuran ini, dapat dilihat bahwa metode yang digunakan dalam penelitian ini, serta penggunaan kitosan sebagai enkapsulan dapat menghasilkan produk nanokapsul berdimensi nanometer.

\section{KESIMPULAN}

Asap cair yang mengandung fenol dapat terkapsulasi dengan baik yang ditunjukkan dengan warna merah kecoklatan di dalam bulatan pada pengamatan dengan mikroskop cahaya. Kondisi optimum untuk total fenol didapatkan pada kondisi konsentrasi kitosan $0.1167 \%$, suhu inlet $140.65^{\circ} \mathrm{C}$ dan laju alir umpan $5.29 \mathrm{~mL} /$ menit. Bentuk nanokapsul yang dihasilkan spherical atau berbentuk bulat, namun terjadi kerut (shrinkage) akan tetapi tidak ada retakan atau pecah pada permukaannya dibandingkan dengan kontrol yang mengalami retak pada permukaan nanokapsulnya. Nanokapsul dengan perlakuan terbaik memiliki ukuran rata-rata $29.16 \mathrm{~nm}$. Dengan demikian, maka metode yang digunakan dan kitosan sebagai enkapsulan mampu menghasilkan produk yang memiliki ukuran nanometer $(\mathrm{nm})$.

\section{UCAPAN TERIMA KASIH}

Penelitian ini didukung oleh Hibah DIKTI. Penulis pertama mengucapkan terima kasih atas dana penelitian dari program beasiswa unggulan DIKTI Kementerian Pendidikan dan Kebudayaan Republik Indonesia.

\section{DAFTAR PUSTAKA}

Ahmed M, Akter MS, Chin KB, Eun JB. 2009. Effect of maltodextrin concentration and drying temperature on quality properties of purple sweet potato flour. Food Sci Biotechnol 18: 1487-1494.

[AOAC] Association of Official Analytical Chemist. 2005. Official Method of Analysis. 18 $18^{\text {th }}$ edition. Association of Official Analytical Chemist. Washington DC, USA.

Bas D, Boyaci IH. 2007. Modelling and optimization I: Usability of response surface methodology. J Food Eng 78: 836845. DOI: 10.1016/j.jfoodeng.2005.11.024.

Caliskan G, Nur DS. 2013. The effects of the different drying conditions and the amounts of maltodextrin addition during spray drying of sumac extract. Food Bioprod Process 91: 539-548. DOI: 10.1016/j.fbp.2013.06.004.

Carvajal MXQ, Diaz BHC, Torres LSM, Perez JJC, Beltran LA, Aparicio AJ, Lopez GFG. 2010. Nanoencapsulation: a new trend in food engineering processing. Food Eng Rev 2: 3950. DOI: 10.1007/s12393-009-9012-6.

Chuah AM, Kuroiwa T, Ichikawa S, Kobayashi I, Nakajima M. 2009. Formation of biocompatible nanoparticles via the selfassembly of chitosan and modified lechitin. J Food Sci 74: N1-N8. DOI: 10.1111/j.1750-3841.2008.00985.x.

Darmadji P, Marsono Y, Suparmo. 2009. Biopreservative Prototype Making of Liquid Smoke, Safety Evaluation and 
Industrial Profile as an Alternative Preservation to Replace Formaldehyde. Report $2^{\text {nd }}$ years Insentive Applied. The Ministry of Research and Technology of Republic of Indonesia.

Deladino L, Anbinder PS, Navarro AS, Martino MN. 2008. Encapsulation of natural antioxidants extracted from llex paraguariensis. Carbohyd Polym 71: 126-134. DOI: 10. 1016/j.carbpol.2007.05.030.

Fernandez-Kim S. 2004. Physicochemical and Functional Properties of Crawfish Chitosan as Affected by Different Processing Protocols [Thesis]. Louisiana: The Department of Food Science, Louisiana State University, USA.

Goula AM, Adamopoulos KG. 2010. A new technique for spray drying orange juice concentrate. Innov Food Sci Emerg 11: 342-351. DOI: 10.1016/j.ifset.2009.12.001.

Harris R, Lecumberri E, Aparicio IM, Mengibar M, Heras A. 2010. Chitosan nanoparticles and microspheres for the encapsulation of natural antioxidants extracted from llex paraguariensis. Carbohyd Polym 84: 803-806. DOI: 10.1016/j.carbpol.2010.07.003.

Kha TC, Nguyen MH, Roach PD. 2010. Effects of spray drying conditions on the physicochemical and antioxidant properties of the Gac (Momordica cochinchinensis) fruit aril powder. J Food Eng 98: 385-392. DOI: 10.1016/j.jfoodeng. 2010.01.016.

Krishnaiah D, Sarbatly, Rao SRM, Nithyanandam RR. 2009. Optimal operating conditions of spray dried noni fruit extract using K-carrageenan as adjuvant. J Appl Sci 9: 3062-3067. DOI: 10.3923/jas.2009.3062.3067.

Krishnaiah D, Sarbatly, R, Nithyanandam RR. 2011. Optimization of spray for drying Morinda citrifolia L. fruit extract. J Appl Sci 11: 1-8. DOI: 10.3923/jas.2011.

Krishnaiah D, Bono A, Sarbatly R, Nithyanandam R, Anisuzzaman SM. 2012. Optimisation of spray drying operating conditions of Morinda citrifolia L. fruit extract using response surface methodology. J King Saud Univ - Eng Sci DOI: 10.1016/j.jksues.2012.10.004. (in press).

Learoyd TP, Burrows JL, French E, Seville PC. 2008. Chitosanbased spray-dried respirable powders for sustained delivery of terbutaline sulfate. Eur J Pharm Biopharm 68: 224-34. DOI: 10.1016/j.ejpb.2007.04.017.

Lee SE, Park KH, Park IS, Na K. 2007. Glycol chitosan as a stabilizer for protein encapsulated into poly (lactide-coglycolide) microparticle. Int J Pharm 338: 310-316. DOI: 10.1016/j.jpharm.2007.02.008.
Rosenberg M, Kopelman IJ, Talmon Y. 1990. Factor affecting retention in spray drying microencapsulation of volatile materials. J Agr Food Chem 38: 1288-1294. DOI: 10.1021/ jf00095a030.

Saenz C, Tapia S, Chavez J, Robert P. 2009. Microencapsulation by spray drying of bioactive compounds from cactus pear (Opuntia ficus-indica). Food Chem 114: 616622. DOI: 10.1016/j.foodchem.2008.09.095.

Saloko S, Darmadji P, Setiaji B, Pranoto Y. 2012. Structural analysis of spray dried coconut shell liquid smoke powder. J Teknol dan Industri Pangan 23: 173-179. DOI: 10.6066/jtip. 2012.23.2.173.

Sekhon BS. 2010. Food nanotechnology - an overview. J Nanotechnology, Science Applications 3: 1-15. DOI: 10.2147/NSA.S8677.

Senter SD, Robertson JA, Meredith FI. 1989. Phenolic compound of the mesocarp of cresthauen peaches during storage and ripening. J Food Sci 54: 1259-1268.

Soloway S, Wilen SH. 1952. Improved ferric chloride test for phenols. Anal Chem 24: 979-983. DOI: 10.1021/ac60 $066 \mathrm{a} 017$.

Sormoli ME, Islam MI, Langrish TAG. 2012. The effect of chitosan hydrogen bonding on lactose crytallinity during spray drying. J Food Eng 108: 541-548. DOI: 10.1016/ j.jfoodeng.2011.09.011.

Tonon RV, Brabet C, Hubinger MD. 2010. Anthocyanin stability and antioxidant activity of spray dried acai (Euterpe oleracea Mart.) juice produced with different carrier agents. Food Res Int 43: 907-914. DOI: 10.1016/j.foodres. 2009.12.013.

Weiss J, Decker EA, McClements DJ, Kristbergsson K, Helgason T, Awad T. 2008. Solid lipid nanoparticles as delivery system for bioactive food components. Food Biophys 3: 146-154. DOI: 10.1007/s11483-008-9065-8.

Yuliana S, Desmawarni, Harimurti N, Yuliani SS. 2007. Pengaruh laju alir umpan dan suhu inlet spray drying pada karakteristik mikrokapsul oleoresin jahe. J Pascapanen 4: 18-26.

Zuidan NJ, Nedovic VA 2010. Encapsulation Technologies for Food Ingredients and Food Processing. Springer, New York.

Zuraida I, Sukarno, Budijanto S. 2011. Antibacterial activity of coconut shell liquid smoke (CS-LS) and its application on fish ball preservation. Int Food Res J 18: 405-410. 